\title{
Динаміка зміни показників координаційних здібностей кваліфікованих волейболісток під впливом використання комплексу вправ та рухливих ігор
}

\author{
Аліна Мельник ${ }^{1}$ \\ Євгенія Стрельникова ${ }^{2}$ \\ Тамара Ляхова' \\ Наталія Пащенко
}

\author{
Харківська державна академія фізичної культури', \\ Харків, Україна,
}

Харківський національний педагогічний університет імені Г. С. Сковороди², Харків, Україна

\begin{abstract}
Мета: вивчення динаміки зміни показників координаційних здібностей кваліфікованих волейболісток під впливом використання комплексу вправ та рухливих ігор.

Матеріал і методи: у роботі використовувались наступні методи дослідження: аналіз науково-методичної літератури; педагогічний експеримент; педагогічне тестування; методи математичної статистики. Під час дослідження проведено педагогічний експеримент, який був спрямований на підвищення рівня координаційних здібностей кваліфікованих волейболісток. Для його проведення була обрана група з 10 кваліфікованих волейболісток віком 18-21 років команди “Харків'янка» (м. Харків), які приймають участь у змаганнях команд вищої ліги України. Для розвитку координаційних здібностей були запропоновані такі засоби як комплекс спеціальних вправ та рухливі ігри, а для їх оцінки були використані відповідні тести.

Результати: аналіз результатів педагогічного експерименту показав, що середньо арифметичні значення показників по кожному з чотирьох обраних тестів після проведення експерименту виявилися значно вищими у порівнянні з результатами відповідних тестів отриманих до початку експерименту. Результати відповідного порівняльного аналізуз використанням критерію Стьюдента довели достовірність різниці між значеннями показників цих тестів.

Висновки: запропоновані засоби для підвищення рівня координаційних здібностей волейболісток виправдали себе, як ефективні. Вони можуть застосовуватися тренерами команд в практичній роботі для підготовки гравців захисного амплуа, що сприятиме підвищенню результативності гри команди в тренувальній та змагальній діяльності.
\end{abstract}

Ключові слова: тест, комплекс вправ, координаційні здібності, педагогічний експеримент, рухливі ігри, волейболістки.

\section{Вступ}

У сучасному волейболі одним з головних факторів досягнення успіху в змагальній діяльності команди $є$ ефективна гра в захисті [9]. Велика кількість аспектів виконання захисних дій волейболістками тісно пов'язана з розвитком їх координаційних здібностей. Тому дана робота присвячена детальному аналізу саме цих здібностей кваліфікованих волейболісток, що приймають участь у захисних діях команди.

у сучасній науково-методичній літературі низка праць $[2 ; 7 ; 10 ; 13 ; 18]$ присвячена вивченню проблем, що пов'язані з вивченням розвитку координаційних здібностей волейболістів.

Так, у праці [8] проведено детальний аналіз літературних джерел, що присвячені розвитку координаційних здібностей у сучасному волейболі. Вивчені різні аспекти розвитку координаційних здібностей волейболісток, що пов'язані з виконанням ними певних техніко-тактичних дій. У праці [12] автори підкреслюють, що для волейболістів надзвичайно важливими є висококоординовані дії 3 м'ячем у безопорному положенні. Для розвитку координаційних здібностей у волейболістів ними рекомендують- ся комплексні вправи, які виконуються в швидкому темпі. У дослідженнях Устінова Т. Б. та Прекурат О.О. [14] запропоновано програму розвитку координаційних здібностей на етапі початкової підготовки волейболістів. На думку авторів, впровадження в тренувальну діяльність методики координаційної підготовки волейболістів сприятиме швидкому та якісному засвоєнню елементів техніки гри у волейбол. Доведено, що система підбору засобів координаційної підготовки повинна передбачати застосування найбільш різноманітних вправ і різних їх поєднань, які спрямовані як на вирішення завдань загальної фізичної підготовки, так і на формування необхідних рухових навичок [13]. У дослідженні авторами Бойчуком Р. І., Коропом М. Ю. та Бєлявським І. Л. [2] доведено, що використання засобів для розвитку спеціальної спритності з елементами техніки волейболу на етапі підготовки волейболістів до вищих досягнень сприяє підвищенню ефективності їх змагальної діяльності.

У праці [7] авторами Коржем Н. Л., Жестковим С. Г., Івановою Н. Б., Барською Н. Л., Чечель М. М. проаналізовано вплив акробатичних вправ на розвиток координаційних здібностей волейболісток у тренувальному 
процесі. Зазначено, що застосування спеціальних акробатичних вправ у поєднанні з грою - найраціональніший шлях розвитку вміння орієнтуватись на майданчику.

Автор у праці [19] вивчає роль координації на початкових етапах підготовки у волейболі, зокрема зазначає, що координаційні здібності, особливо в період статевого дозрівання, відіграють важливу роль у створенні передумов для розвитку фізичної підготовленості та набуття рухових навичок. Запропоновано модель розвитку координаційних здібностей.

Дослідження [20] присвячено впливу координації на точність передачі м'яча у волейболі, як важливого чинника ефективності його виконання у грі. Підкреслено, що координація міцно пов'язана з технікою та точністю передачі. Для покращення точності виконання передачі рекомендовано в тренувальному процесі приділяти особливу увагу створенню великої кількості різноманітних структур руху, що може сприяти більш повному формуванню координації у волейболістів.

Проведено факторний аналіз, який дозволив отримати структуру координаційних здібностей волейболісток $з$ п'яти відповідних компонентів, що значною мірою впливають на формування їх техніко-тактичної підготовленості [16]. Рекомендовано використовувати ігрові вправи та кругові тренування для покращення специфічних координаційних здібностей волейболісток.

Розроблено та експериментально перевірено методику використання координаційної драбини для вдосконалення технічних навичок та психофізіологічних функцій юних волейболістів [18]. Визначено їі позитивний вплив на якість тренувального процесу волейболістів.

Аналіз літературних джерел показав, що вдосконаленню координаційних здібностей гравців, які беруть участь в організації захисту, приділялось недостатньо уваги.

Мета дослідження - вивчення зміни показників координаційних здібностей кваліфікованих волейболісток під впливом використання спеціальних засобів.

\section{Матеріал і методи дослідження}

У статті використовувались наступні методи дослідження: аналіз науково-методичної літератури; педагогічний експеримент; педагогічне тестування; методи математичної статистики Проведено послідовний педагогічний експеримент, що був спрямований на підвищення рівня координаційних здібностей кваліфікованих волейболісток та тривав 12 тижнів. У дослідженні взяли участь 10 волейболісток віком 18-21 років команди «Харків'янка», які приймають участь у змаганнях команд вищої ліги України. Для оцінки координаційних здібностей волейболісток в процесі педагогічного експерименту використовувались відповідні тести. Час проведення тестів, характер відпочинку між спробами були постійними для усіх волейболісток, що брали участь в експерименті.

\section{Результати дослідження}

Розвиток фізичних якостей волейболісток полягає в тому, щоб у процесі занять фізичними вправами розвивати швидкість, силу, спритність, витривалість. Цей процес тісно пов'язаний з формуванням рухових навичок i зумовлений обсягом і характером рухової активності. Від рівня розвитку рухових якостей залежать результати виконання технічних елементів гри $[1 ; 5]$.
Для гравців, які виконують певні функції в ігрових діях, в ході гри немає необхідності різнобічного розвитку всіх фізичних якостей. Так, гравцям захисного плану основну увагу потрібно приділяти тільки тим з них, які відіграють значну роль у вирішенні специфічних завдань виконання відповідних технічних прийомів гри, в яких їм доводиться брати участь. Зокрема, для них важливе значення має розвиток координаційних здібностей. Вони проявляються в умінні швидко перебудовувати свої дії, які органічно пов'язані з силою, швидкістю, витривалістю, спритністю, відповідно до миттєвої зміни ігрової ситуації на майданчику. Координаційні здібності захисника проявляються в кидках, падіннях, перекатах під час гри в захисті [3].

Що стосується розвитку координаційних здібностей, то до основних засобів відносяться акробатичні, імітаційні вправи елементів техніки гри у волейбол та рухливі ігри. 3 цією метою у тренувальному процесі використовують найрізноманітніші вправи, в яких гравець повинен виходити з несподіваних ситуацій на майданчику за допомогою кмітливих і швидких дій [8; 11].

Серед фізичних якостей волейболісток координаційні здібності займають особливе місце. Високий рівень їх розвитку $є$ вирішальною передумовою для якісного освоєння і вдосконалення техніки гри. Гравець 3 високим рівнем розвику координації швидко пристосовується до постійно мінливих умов у грі і вибирає найбільш ефективні засоби її ведення [6; 19].

Виконання будь-якого технічного прийому будується на основі старих координаційних зв'язків. Чим більший запас різноманітних рухових навичок має гравець, тим успішнішим $€$ оволодіння технікою гри. У зв'язку 3 цим основний шлях розвитку координаційних здібностей - це збагачення гравців новими різноманітними навичками і вміннями, розвиток координації рухів [17].

Основними засобами розвитку координаційних здібностей волейболісток $є$ фізичні вправи підвищеної координаційної складності, які містять елементи новизни. Складність фізичних вправ можна збільшити за рахунок зміни просторових, часових і динамічних параметрів, а також за рахунок зовнішніх умов, комбінуючи рухові навички, поєднуючи ходьбу зі стрибками, біг і ловлю предметів, виконуючи вправи за сигналом або з обмеженим проміжком часу [19].

Особливу групу засобів складають також вправи з виховання почуття простору, часу, ступеню розвитку м'язових зусиль. Вправи, що спрямовані на розвиток координаційних здібностей, ефективні до тих пір, поки вони не будуть виконуватися автоматично. Потім вони втрачають свою ефективність, оскільки будь-яка навичка, яка була освоєна до цього моменту, не стимулює подальшого розвитку координаційних здібностей [15].

Метою запропонованого нами педагогічного експерименту $€$ підвищення показників координаційних здібностей 10 кваліфікованих волейболісток, які приймають участь у захисних діях команди “Харків'янка». Зазначимо, що центральні блокуючі не були задіяні в експерименті, так як вони майже не приймають участь у захисних діях команди у змагальній діяльності.

Після проведення первинного тестування даної групи волейболісток до початку експерименту в тренувальний процес був впроваджений запропонований нами комплекс спеціальних вправ та рухливі ігри, що сприятимуть, на наш погляд, розвитку координаційних здібнос- 


\section{СЛОБОЖАНСЬКИЙ НАУКОВО-СПОРТИВНИЙ ВІСНИК}

\section{Діаграма зміни середньоарифметичних показників відповідних тестів після проведення педагогічного експерименту}

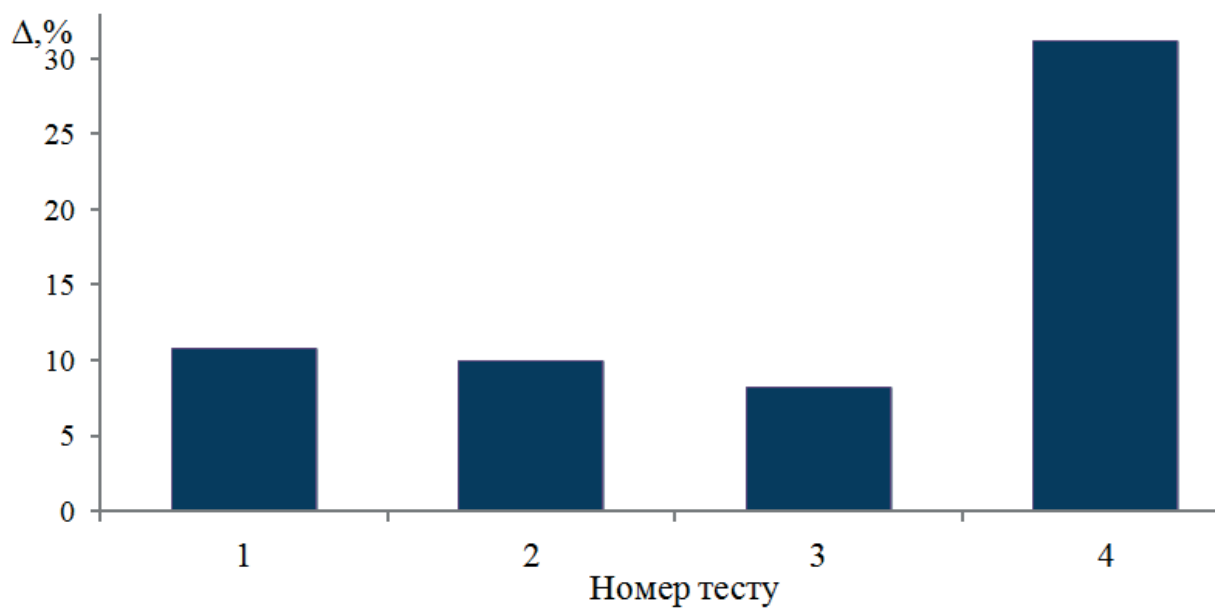

Примітка:

Тест 1. Старт з лицьової лінії майданчика. Перекид вперед, біг по гімнастичній лаві, імітація нападаючого удару біля сітки, страховка на лінії нападу, перекид назад, біг до лицьової лінії.

Тест 2. Біг по периметру одного боку майданчика проти годинникової стрілки. Набивні м'ячі № 1, 2, 3 лежать на лінії нападу: №1 і 3 на відстані 1 м від бічної лінії, №2 - на середині. Два гравця, які розташовані між м'ячами № 1 і 2 та 2 і 3, тримають обручі вертикально до підлоги. Старт із зони 1. Прискорення до м'яча №1, взяти м'яч, розбіг для нападаючого удару і кидок двома руками через сітку в зону нападу; пролізти в обруч, ривок до м'яча №2 і далі ті ж дії. Після кидка м'яча №3 через сітку гравець фінішує бігом спиною вперед уздовж бічної лінії до лицьової.

Тест 3. Човниковий біг 546 м з переносом кубиків.

Тест 4. Імітація блока біля сітки, страховка на лінії нападу потім перекид назад. Виконання передачі м'яча знизу двома руками на точність у мішень послідовно з 8, 6, 3 м по 5 разів з кожної точки. Втраченими вважаються передачі, які не потрапили в межі мішені.

тей волейболісток. Ці засоби волейболістки використовували 2 рази на тиждень у спеціально-підготовчій або на початку основної частини тренувального заняття протягом 12 тижнів. При виконанні запропонованого комплексу вправ застосовувався повторний метод та метод «кругового тренування», як найбільш ефективні.

Використовувались такі спеціальні засоби, наприклад:

В парах: перший гравець з м'ячем біля стінки, другий на лицьовій лінії в різних вихідних положеннях (сидячи обличчям або спиною до партнера, лежачи на животі або на спині), перший гравець ударяє м'ячем у підлогу, другий після відскоку м'яча від підлоги повинен наздогнати м'яч і виконати передачу знизу двома руками партнерові.

Волейболістки діляться на дві рівні команди, які вишиковуються в колони. За сигналом тренера вони з розгону виконують підряд чотири падіння, імітуючи прийом м'яча з перевертом через праве і ліве плече, далі роблять ривок на 10-15 м і стрибками на двох ногах повертаються до відповідної колони. Далі наступний гравець і т. д. Перемагає та команда, яка швидше і з меншою кількістю помилок закінчить естафету.

Після використання запропонованого комплексу вправ та рухливих ігор було проведене повторне тестування даної групи волейболісток. У результаті проведення серії тестів волейболісток до початку та після проведення експерименту були одержані відповідні статистичні дані показників їх координаційних здібностей.

Результати абсолютної величини приросту середньоарифметичних показників після проведення експерименту відносно їх значень, що були отримані до початку його проведення наведено на рис. 1.
Як видно з рис. 1, найбільший приріст за абсолютною величиною здобуло розраховане значення показника тесту № 4 - 31,2\%, найнижчий приріст одержав результат тесту №3 - на рівні $8,2 \%$, результати для значень тестів 1, 2 покращились на 10,8\%, 9,9\% у порівнянні з результатами відповідних тестів, що були одержані до початку проведення експерименту.

Результати порівняльного аналізу середньо статистичних значень показників координаційних здібностей волейболісток у педагогічному експерименті наведені в табл. 1.

Виходячи з його результатів, можна зробити висновок, що значення всіх показників збільшились після проведення педагогічного експерименту. Тобто використання запропонованого комплексу різноманітних спеціальних вправ та рухливих ігор у тренувальному процесі волейболісток під час проведення експерименту, забезпечило такий ефект. Однією з причин покращення відповідних результатів є застосування у тренувальній діяльності різних завдань, що викликали у гравців більший інтерес і у зв'язку з цим підвищувалася мотивація до виконання цих вправ та рухливих ігор.

Проведено оцінку статистичної достовірності відмінностей результатів порівняльного аналізу середньо статистичних значень показників даних тестів, що були визначені до початку та після проведення педагогічного експерименту з використанням критерію Стьюдента [4]. Оскільки значення критерію Стьюдента $\mathrm{t}>\mathrm{trp}$, відмінність між розрахованими показниками для всіх тестів статистично достовірна. 3 огляду на достовірну позитивну зміну значень, впровадження запропонованого комплексу вправ 


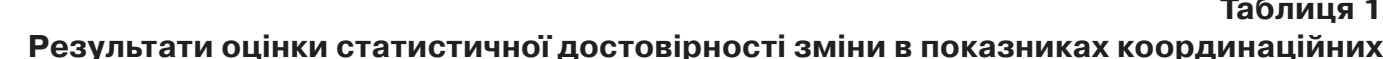
здібностей кваліфікованих волейболісток у педагогічному експерименті (n1=n2=10)

\begin{tabular}{|c|c|c|c|c|c|}
\hline \multirow[t]{2}{*}{$\begin{array}{c}\text { № } \\
\Pi / \Pi\end{array}$} & \multirow[t]{2}{*}{ Номер тесту } & $\begin{array}{c}\text { до } \\
\text { експерименту }\end{array}$ & $\begin{array}{c}\text { після } \\
\text { експерименту }\end{array}$ & \multirow[t]{2}{*}{$\mathrm{t}$} & \multirow[t]{2}{*}{$\mathrm{p}$} \\
\hline & & \multicolumn{2}{|c|}{$\bar{X} \pm \sigma$} & & \\
\hline 1 & Тест №1, (c) & $9,26 \pm 0,58$ & $8,26 \pm 0,49$ & 3,95 & $<0,05$ \\
\hline 2 & Тест №2, (c) & $15,54 \pm 1,30$ & $14,00 \pm 1,10$ & 2,71 & $<0,05$ \\
\hline 3 & Тест №3, (c) & $9,55 \pm 0,51$ & $8,77 \pm 0,42$ & 3,53 & $<0,05$ \\
\hline 4 & Тест №4, (кількість разів) & $6,10 \pm 1,90$ & $4,20 \pm 1,30$ & 2,48 & $<0,05$ \\
\hline
\end{tabular}

та рухливих ігор у практику тренувального процесу кваліфікованих волейболісток можна вважати ефективним. Результати проведеного нами дослідження дозволяють рекомендувати запропоновані нами засоби для широкого використання тренерами в тренувально-змагальній діяльності для покращення значень даних показників координаційних здібностей гравців захисного плану.

\section{Висновки / Дискусія}

Проведено педагогічний експеримент, що був спрямований на підвищення рівня розвитку спритності кваліфікованих волейболісток. У ньому використовувався запропонований нами комплекс спеціальних вправ та рухливі ігри, які сприяють розвитку спритності волейболісток. Ефективність його впровадження для підвищення рівня спритності волейболісток оцінювалась за допомогою чотирьох спеціально підібраних нами тестів. Порівняльний аналіз результатів проведеного тестування показав, що середньо арифметичні показники по кожному тесту, що були отримані після експерименту виявилися значно вищими, ніж до початку його проведення.

Таким чином, можна зробити висновок, що запропоновані засоби для підвищення рівня координаційних здібностей волейболісток виправдали себе, як ефективні, та можуть застосовуватися тренерами команд в практичній роботі для підготовки гравців захисного амплуа.

Перспективи подальших досліджень - вивчення впливу координаційних здібностей кваліфікованих волейболісток на кількісні показники ефективності виконання захисних дій у змагальній діяльності жіночих команд вищої ліги.

Конфлікт інтересів. Автори заявляють, що немає конфлікту інтересів, який може сприйматися як такий, що може завдати шкоди неупередженості статті.

Джерела фінансування. Ця стаття не отримала фінансової підтримки від державної, громадської або комерційної організації.

\section{Список посилань}

1. Бондаренко В. В., Ціпов'яз А. Т. (2018), Методика навчання елементам техніки волейболу: навчально-методичний посібник. Кременчук, 120с.

2. Бойчук Р. І., Короп М. Ю., Бєлявський І. Л. (2019), «Значущість спритності та координації для успішної ігрової діяльності волейболістів на етапі підготовки до вищих досягнень», Вісник Національного університету «Чернігівський колегіум» імені Т. Г. Шевченка, Вип. 3 (159), С. 330-334.

3. Гнатчук Я. (2007), «Аналіз ефективності різних методичних підходів до змісту фізичної підготовки кваліфікованих волейболістів», Молода спортивна наука України, Т. 3, С. 97-103.

4. Денисова Л. В., Хмельницкая И. В. \& Харченко Л. А. (2008), Измерения и методы математической статистики в физическом воспитании и спорте: учебное пособие для вузов. Киев, 127 с.

5. Засоби та методи фізичної підготовки (2019), Дніпро: ПДАФКіС, 17 с.

6. Козина Ж. Л., Гринченко И. Б., Крамской С. И., Поярков Ю. М. (2013), Спортивные игры: учебник для студентов педагогических вузов в 2-х томах. Том 1. Харьков. 446 с.

7. Корж Н. Л., Жестков С. Г., Іванова Н. Б., Барська Н. Л. \& Чечель М. М. (2007), «Вплив акробатичних вправ на розвиток координаційних здібностей волейболісток», Педагогіка, психологія та медико-біологічні проблеми фізичного виховання і спорту, №6, С. 152-155.

8. Мельник А. Ю. (2021), «Роль координаційних здібностей волейболісток у виконанні захисних дій», Проблеми і перспективи розвитку спортивних ігор і єдиноборств у закладах вищої освіти: збірник статей XVII міжнародної науково-практичної конференції, 5 лютого 2021 р., Харків, С. 55-58.

9. Мельник А. Ю. (2019), «Аналіз ігрових дій «ліберо» у змагальній діяльності волейболісток», Проблеми і перспективи розвитку спортивних ігор і єдиноборств у закладах вищої освіти: збірник статей XV міжнародної науково-практичної конференції, 8-9 лютого 2019 р., Харків, С. 37-40.

10. Мошенська Т., Петров Д. (2020), «Удосконалення фізичних якостей волейболістів з використанням засобів аеробіки на етапі спеціалізованої базової підготовки», Слобожанський науково-спортивний вісник, № 1(75), С. 122-126.

11. Остапенко Ю. О. (2012), «Комплексний контроль розвитку координаційних здібностей студентів української академії банківської справи», Слобожанський науково-спортивний вісник, №2(29), С. 22-26.

12. Стратій Н. В., Грищенко О. І., Істомін А. Г., Веретельникова Ю. А., Куций Д. В. \& Посипайко А. О. (2012), Методика навчання техніки гри у волейбол студентів вищих навчальних закладів: навчальний посібник. Харків, 104 с. 
13. Сапрун С. Т., Корнієнко С. М. (2018), «Методика розвитку координаційних здібностей юних волейболістів на тренувальних заняттях з волейболу», Науковий часопис НПУ імені М.П. Драгоманова, Вип. 4(98), С. 141-144.

14. Устінова Т. Б. \& Прекурат О. О. (2009), «Методика розвитку координаційних здібностей юних волейболістів на етапах початкової підготовки", Педагогіка, психологія та медико-біологічні проблеми фізичного виховання і спорту, №8, С.153-156.

15. Шиян В. М. (2013), «Особливості розвитку координаційних здібностей бадмінтоністів на етапі попередньої базової підготовки», Слобожанський науково-спортивний вісник, № 5, С. 286-290.

16. Boichuk R., lermakov S., Nosko M. \& Kovtsun V. (2017), «Special aspects of female volleyball players' coordination training at the stage of specialized preparation», Journal of Physical Education and Sport, 17(2), pp. 884-891.

17. Bykova O., Druz V., Pomeshchikova I., Strelnikova E., Strelnikov Gleb, Melnyk A. \& Shyriaieva I. (2017), «Changes in technical preparedness of 13-14 - year-old handball players under the influence of coordination orientation exercises", Journal of Physical Education and Sport, 17(3), Art 185, pp.1899-1905

18. Kozina Z., Goloborodko Y., BoichukY., Sobko I., Repko O., Bazilyuk T., Prokopenko I., Prokopenko I., Prokopenko A., Tararak N, Osiptsov A., Kostiukevych V., Guba A., Trubchaninov M., Polianskyi A., Rostovska V., Drachuk A. \& Stsiuk I. (2018), «The influence of a special technique for developing coordination abilities on the level of technical preparedness and development of psycho-physiological functions of young volleyball players 14-16 years of age», Journal of Physical Education and Sport, 18(3), Art 214, pp. $1445-1454$.

19. Simonek J. (2014), Coordination abilities in Volleyball. Warszaw/Berlin, 80 p.

20. Stojanović N., Stojanovic T., Stojanović D. \& Herodek K. (2014), «The influence of coordination abilities on the precision of forearm passing in volleyball», Defendologija, 1(35), pp. 75-84.

Стаття надійшла до редакції: 15.03.2021 р.

Опубліковано: 26.04.2021 р.

Аннотация. Алина Мельник, Евгения Стрельникова, Тамара Ляхова, Наталия Пащенко. Изменение показателей координационных способностей квалифицированных волейболисток под влиянием использования комплекса упражнений и подвижных игр. Цель: изучение динамики изменения показателей координационных способностей волейболисток под влиянием использования комплекса упражнений и подвижных игр. Материал и методы: в работе использовались следующие методы исследования: анализ научно-методической литературы; педагогический эксперимент; педагогическое тестирование; методы математической статистики. В ходе исследования проведен педагогический эксперимент, который был направлен на повышение уровня координационных способностей квалифицированных волейболисток. Для его проведения была выбрана группа из 10 квалифицированных волейболисток в возрасте 18-21 лет команды «Харьковчанка» (г. Харьков), которые принимают участие в соревнованиях команд высшей лиги Украины. Для развития координационных способностей были предложены такие средства как комплекс специальных упражнений и подвижные игры, а для их оценки были использованы соответствующие тесты. Результаты: анализ результатов педагогического эксперимента показал, что среднеарифметические значения показателей по каждому из четырех выбраных тестов после проведения эксперимента оказались значительно выше по сравнению с результатами соответствующих тестов, полученных до начала эксперимента. Результаты соответствующего сравнительного анализа с использованием критерия Стьюдента доказали достоверность разницы между значениями показателей этих тестов. Выводы: предложенные средства для повышения уровня координационных способностей волейболисток оправдали себя как эффективные. Они могут применяться тренерами команд в практической работе для подготовки игроков защитного амплуа, что будет способствовать повышению результативности игры команды в тренировочной и соревновательной деятельности.

Ключевые слова: тест, комплекс упражнений, координационные способности, педагогический эксперимент, подвижные игры, волейболистки.

Abstract. Alina Melnyk, levgeniia Strelnykova, Tamara Liakhova, Natalya Pashchenko. The dynamics of change in indicators of coordination abilities of qualified female volleyball players under the influence of using a set of exercises and outdoor games. Purpose: to study the dynamics of changes in coordination abilities of qualified female volleyball players under the influence of using a set of exercises and outdoor games. Material and methods: the following research methods were used in the research: analysis of scientific and methodological literature; pedagogical experiment; pedagogical testing; methods of mathematical statistics. During the research, the pedagogical experiment was conducted and aimed at increasing the level of coordination abilities of qualified female volleyball players. A group of 10 qualified female volleyball players at the age of 18-21 years of the team "Kharkivyanka" (Kharkiv) was chosen for its holding, who takes part in competitions of teams of the Major League of Ukraine. Such means as a set of special exercises and outdoor were proposed for the development of coordination abilities, and appropriate tests were used to evaluate them. Results: the analysis of the results of the pedagogical experiment showed that the average arithmetic values of the indicators for each of the four selected tests after the experiment were significantly higher compared to the results of the corresponding tests obtained before the experiment. The results of the corresponding comparative analysis using the Student's test proved the validity of the difference between values of the indicators of these tests. Conclusions: the proposed means to increase the level of coordination abilities of female volleyball players justified themselves as effective. They can be used by team coaches in practical work to prepare players for a defensive role, which will contribute to improving the team's game performance in training and competitive activities.

Keywords: test, a set of exercises, coordination abilities, pedagogical experiment, outdoor, female volleyball players.

\section{References}

1. Bondarenko, V. V. \& Tsipoviaz, A. T. (2018), Metodyka navchannia elementam tekhniky voleibolu: navchalno-metodychnyi posibnyk. Kremenchuk, 120 p. (in Ukr.).

2. Boichuk, R. I., Korop, M. Yu. \& Bieliavskyi, I. L. (2019), «The importance of agility and coordination for the successful game activity of volleyball players at the stage of preparation for higher achievements», Visnyk Natsionalnoho universytetu «Chernihivskyi kolehium» imeni T. H. Shevchenka, Vyp. 3 (159), pp. 330-334. (in Ukr.).

3. Hnatchuk, Ya. (2007), «Analysis of the effectiveness of various methodological approaches to the content of physical training of qualified volleyball players», Moloda sportyvna nauka Ukrainy, Vol. 3, pp. 97-103. (in Ukr.).

4. Denisova, L. V., Khmelnitckaia, I. V. \& Kharchenko, L. A. (2008), Izmereniia i metody matematicheskoi statistiki v fizicheskom vospitanii i sporte: uchebnoe posobie dlia vuzov. Kiev, 127 p. (in Russ.).

5. Zasoby ta metody fizychnoi pidhotovky (2019), Dnipro: PDAFKiS, 17 p. (in Ukr.). 
6. Kozina, Zh. L., Grinchenko, I. B., Kramskoi, S. I. \& Poiarkov, lu. M. (2013), Sportivnye igry: uchebnik dlia studentov pedagogicheskikh vuzov v 2-kh tomakh. Tom 1, Kharkov, 446 p. (in Russ.).

7. Korzh, N. L., Zhestkov, S. H., Ivanova, N. B., Barska, N. L. \& Chechel, M. M. (2007), «The influence of acrobatic exercises on the development of coordination abilities of volleyball players", Pedahohika, psykholohiia ta medyko-biolohichni problemy fizychnoho vykhovannia i sportu, No. 6, pp. 152-155. (in Ukr.).

8. Melnyk, A. Yu. (2021), «The role of coordination abilities of volleyball players in performing protective actions», Problemy $i$ perspektyvy rozvytku sportyvnykh ihor i yedynoborstv u zakladakh vyshchoi osvity: zbirnyk statei VII mizhnarodnoi naukovo-praktychnoi konferentsii, 5 liutoho 2021 r., Kharkiv, pp. 55-58. (in Ukr.).

9. Melnyk, A. Yu. (2019), «Analysis of «libero» game actions in competitive activity of volleyball players», Problemy i perspektyvy rozvytku sportyvnykh ihor i yedynoborstv u zakladakh vyshchoi osvity: zbirnyk statei KhV mizhnarodnoi naukovo-praktychnoi konferentsii, 8-9 liutoho 2019 r., Kharkiv, pp. 37-40. (in Ukr.).

10. Moshenska, T. \& Petrov, D. (2020), «Improving the physical qualities of volleyball players using aerobics at the stage of specialized basic training», Slobozhanskyi naukovo-sportyvnyi visnyk, No. 1(75), pp. 122-126. (in Ukr.).

11. Ostapenko, Yu. O. (2012), "Comprehensive control of the development of coordination abilities of students of the Ukrainian Academy of Banking", Slobozhanskyi naukovo-sportyvnyi visnyk, No. 2(29), pp. 22-26. (in Ukr.).

12. Stratii, N. V., Hryshchenko, O. I., Istomin, A. H., Veretelnykova, Yu. A., Kutsyi, D. V. \& Posypaiko, A. O. (2012), Metodyka navchannia tekhniky hry u voleibol studentiv vyshchykh navchalnykh zakladiv: navchalnyi posibnyk. Kharkiv, 104 p. (in Ukr.).

13. Saprun, S. T. \& Korniienko, S. M. (2018), «Methods of developing coordination abilities of young volleyball players in volleyball training sessions», Naukovyi chasopys NPU imeni M.P. Drahomanova, Vyp. 4(98), pp. 141-144. (in Ukr.).

14. Ustinova, T. B. \& Prekurat, O. O. (2009), «Methods of developing coordination abilities of young volleyball players at the stages of initial training", Pedahohika, psykholohiia ta medyko-biolohichni problemy fizychnoho vykhovannia i sportu, No.8, pp. 153-156. (in Ukr.).

15. Shyian, V. M. (2013), «Features of the development of coordination abilities of badminton players at the stage of preliminary basic training", Slobozhanskyi naukovo-sportyvnyi visnyk, No. 5, pp. 286-290. (in Ukr.).

16. Boichuk, R., lermakov, S., Nosko, M. \& Kovtsun, V. (2017), «Special aspects of female volleyball players' coordination training at the stage of specialized preparation", Journal of Physical Education and Sport, 17(2), pp. 884-891. (in Eng.).

17. Bykova, O., Druz, V., Pomeshchikova, I., Strelnikova, E., Strelnikov, G., Melnyk, A. \& Shyriaieva, I. (2017), «Changes in technical preparedness of 13-14 - year-old handball players under the influence of coordination orientation exercises", Journal of Physical Education and Sport, 17(3), Art 185, pp.1899-1905. (in Eng.).

18. Kozina, Z., Goloborodko, Y., Boichuk, Y., Sobko, I., Repko, O., Bazilyuk, T., Prokopenko, I., Prokopenko, I., Prokopenko, A., Tararak, N., Osiptsov, A., Kostiukevych, V., Guba, A., Trubchaninov, M., Polianskyi, A., Rostovska, V., Drachuk, A. \& Stsiuk, I. (2018), «The influence of a special technique for developing coordination abilities on the level of technical preparedness and development of psycho-physiological functions of young volleyball players 14-16 years of age», Journal of Physical Education and Sport, 18(3), Art 214, pp. 1445-1454. (in Eng.).

19. Simonek, J. (2014), Coordination abilities in Volleyball. Warszaw/Berlin, 80 p. (in Eng.).

20. Stojanović, N., Stojanovic, T., Stojanović, D. \& Herodek, K. (2014), «The influence of coordination abilities on the precision of forearm passing in volleyball», Defendologija, 1(35), pp. 75-84. (in Eng.).

Received: 15.03 .2021

Published: 26.04 .2021

\section{Відомості про авторів / Information about the Authors}

Мельник Аліна Юріївна: к.фіз.вих., доцент; Харківська державна академія фізичної культури: вул. Клочківська 99, Харків, 61058, Україна. Мельник Алина Юрьевна: к.физ. восп., доцент; Харьковская государственная академия физической культуры: ул. Клочковская 99, г. Харьков, 61058, Украина.

Alina Melnyk: PhD (Physical education and Sport), Associate Professor; Kharkiv State Academy of Physical Culture: Klochkivska str. 99, Kharkiv, 61058, Ukraine.

ORCID: https://orcid.org/0000-0001-5612-0333

E-mail: alina.melnik1987@ukr.net

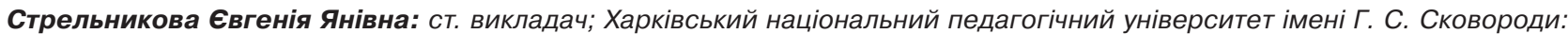
вул. Алчевських 29, Харків, 61002, Україна.

Стрельникова Евгения Яновна: ст. преподаватель; Харьковский национальный педагогический университет имени Г. С. Сковороди: ул. Алчевских 29, Харьков, 61002, Украина.

levgeniia Strelnykova: assistent; H.S. Skovoroda Kharkivnational pedagogical university: Alchevskykh Street 29, Kharkiv, 61002, Ukraine.

ORCID: https://orcid.org/0000-0003-0010-6369

E-mail: zenastrel@gmail.com

Ляхова Тамара Петрівна: ст. викладач; Харківськадержавна академія фізичної культури: вул. Клочківська 99, Харків, 61058, Україна. Ляхова Тамара Петровна: ст. преподаватель; Харьковская государственная академия физической культуры: ул. Клочковская 99, 61058, г. Харьков, Украина.

Tamara Liakhova: assistent; Kharkiv State Academy of Physical Culture: Klochkivska str. 99, Kharkiv, 61058, Ukraine.

ORCID: https://orcid.org/0000-0003-4853-0513

E-mail: tamara.liakhova@yandex.ru

Пащенко Наталія Олександрівна: ст. викладач; Харківська державна академія фізичної культури: вул. Клочківська, 99, Харків, 61058, Україна.

Пащенко Наталия Александровна: ст. преподаватель; Харьковская государственная академия физической культуры: ул. Клочковская, 99, Харьков, 61058, Украина.

Natalya Pashchenko: assistent; Kharkov State Academy of Physical Culture: Klochkivska str. 99, Kharkiv, 61058, Ukraine.

ORCID: https://orcid.org/0000 0003-3219-9248

E-mail: paschenko130@ukr.net 